\title{
Changes in lysosomal hydrolase activity associated with malnutrition in young rats
}

\author{
By ANNE ROOBOL and G. A. O. ALLEYNE \\ Tropical Metabolism Research Unit and Department of Medicine, \\ University of the West Indies, Mona, Kingston 7, Jamaica

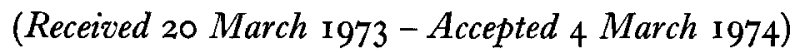

\begin{abstract}
I. Total lysosomal hydrolase activities were measured in liver, gastrocnemius muscle and plasma of malnourished and normal rats between 3 and 8 weeks of age.

2. Concurrently, the DNA and protein contents of the livers and muscles were determined.

3. Increased amounts of acid hydrolase activities were found to be associated with subnormal protein: DNA ratios in the tissues of malnourished rats.

4. It was concluded that lysosomal enzymes may be involved in protein catabolism during malnutrition.
\end{abstract}

When rats are given a protein-deficient diet there is a marked loss of protein nitrogen from the body. During the first $3 \mathrm{~d}$ this is largely associated with protein depletion of the viscera, while in prolonged experiments the main source of $\mathrm{N}$ loss is skeletal muscle (Mendes \& Waterlow, 1958; Munro, 1964). Adaptive changes in the rate of protein synthesis can in part account for the net loss of protein. After only $3 \mathrm{~d}$ on a low protein intake, there is a $20-30 \%$ decrease in the synthesis rate of muscle protein with a smaller increase in catabolic rate (Millward, 1970). However, there is no change in the rate of synthesis of liver protein at this time (Waterlow \& Stephen, 1968), although there is considerable net loss of $\mathrm{N}$ from this organ, indicating that there is increased catabolism.

Very little is known about the mechanism and control of protein catabolism (Waterlow \& Alleyne, I971). Skeletal muscle atrophy arising from vitamin E deficiency (Koszalka, Mason \& Krol, I96ı ; Zalkin, Tappel, Caldwell, Shibko, Desai \& Holliday, I962), genetic muscular dystrophy ('Tappel, Zalkin, Caldwell, Desai \& Shibko, I962) or disuse (Max, Mayer \& Vogelsang, I97I) is associated with a rise in lysosomal hydrolase activity. There is little information about the role of lysosomal enzyme activity in protein catabolism in tissues of the malnourished animal. Bird, Berg \& Leatham (I968) found an increase in total cathepsin activity in both liver and skeletal muscle of rats restricted to $25 \%$ of the $a d l i b$. intake of a diet containing $200 \mathrm{~g}$ casein/ $\mathrm{kg}$ for $5 \mathrm{~d}$. Millward (1972), however, could detect an increase in proteolytic activity in skeletal muscle of rats maintained on a protein-free diet for $24 \mathrm{~d}$ only when the animals were in a terminal state. Starvation in adult rats for $4^{-6} \mathrm{~d}$ leads to formation of autophagic vacuoles and an increase in acid hydrolase content of liver (Novikoff, Essner \& Quintana, 1964). Increased amounts of lysosomal hydrolase activities in the urine and serum of patients with kwashiorkor have been reported (Ittyerah, Dumm \& Bachhawat, I967; Begum \& Ittyerah, 1970).

The aim of this study was to determine the relationship, if any, between lysosomal 
hydrolase activity and changes in composition of tissues of young rats when they were malnourished and after rehabilitation.

\section{EXPERIMENTAL}

\section{Animals and diets}

Sprague-Dawley rats of a locally bred strain were used. Two models of malnutrition were studied. To obtain protein-energy deficient (PED) rats, newborn animals were suckled in large litters (sixteen pups/dam) until they were $2 \mathrm{I} d$ of age: only rats which were $60 \%$ or less of the expected weight-for-age were studied in this group (Kennedy, 1957; Widdowson \& McCance, 1960). Protein-deficient rats were weaned after a normal suckling history (eight pups/dam) at $2 \mathrm{I} \mathrm{d} \mathrm{of} \mathrm{age} \mathrm{onto} \mathrm{an} \mathrm{ad} \mathrm{lib.} \mathrm{diet} \mathrm{containing}$ Io g protein $/ \mathrm{kg}$ (Flores, Sierralta \& Monckeberg, 1970) and maintained on this regimen for $5^{-20} \mathrm{~d}$. A number of rats from each group were rehabilitated on an ad lib. diet of Purina laboratory chow (230 g protein $/ \mathrm{kg}$ ) and killed after 6 or $15 \mathrm{~d}$. Control rats were suckled eight pups/dam and weaned at $21 \mathrm{~d}$ of age onto an ad lib. diet of Purina laboratory chow.

Malnourished rats were compared with control rats of the same age. Variation between litters was avoided by pooling litters at the start of the dietary regimens and placing randomly selected animals in the control and malnourished groups.

\section{Analytical procedures}

Before slaughter, all animals were injected intraperitoneally with 500 I.U. heparin. After $5 \mathrm{~min}$ the animals were stunned and killed by decapitation and $\mathrm{r}-2 \mathrm{ml}$ blood was collected from each animal, placed in separate chilled containers and used for immediate analysis. Livers and gastrocnemius muscles were removed from each animal and placed in separate chilled containers.

\section{Materials}

All chemicals were Analar grade. Biochemicals were purchased from the Sigma Chemical Co., St Louis, Missouri, USA. 'Pularin' heparin injection was obtained from Evans Medical Ltd, Speke, Liverpool, UK.

\section{Estimation of $D N A$ and protein content}

The DNA and protein content of liver and gastrocnemius muscle were determined for each rat. For DNA estimation $c .100 \mathrm{mg}$ samples of fresh tissue were homogenized in $5 \mathrm{ml}$ ice-cold perchloric acid $(33.3 \mathrm{ml} 60 \%$ perchloric acid/1). After centrifugation, at $1200 \mathrm{~g}$ for $15 \mathrm{~min}$, the precipitates were washed twice with ice-cold perchloric acid $(33.3 \mathrm{ml} 60 \%$ perchloric acid $/ \mathrm{l})$, then stored at $-20^{\circ}$ for $\mathrm{I}-3$ weeks. DNA was subsequently extracted from these precipitates and estimated by the method of Munro \& Fleck (I969) with standard solutions containing Io-100 $\mu \mathrm{g}$ DNA (Sigma Chemical Co. $) / \mathrm{ml}$ perchloric acid $(133.3 \mathrm{ml} 60 \%$ perchloric acid $/ \mathrm{l})$.

Protein, in samples of fresh tissue $(25-50 \mathrm{mg})$ which had been digested with 
$2 \mathrm{M}-\mathrm{NaOH}$ overnight, was estimated by the method of Lowry, Rosebrough, Farr $\&$ Randall (I95I) with standard solutions containing I0-100 $\mu \mathrm{g}$ bovine serum albumin, fraction V (Sigma Chemical Co.)/ml o. $5 \mathrm{M}-\mathrm{NaOH}$.

\section{Estimation of acid hydrolase activity}

Fresh tissue samples were homogenized in 9 vol. (w/v) (liver) or 4 vol. (w/v) (muscle) of ice-cold $0.25 \mathrm{M}$-sucrose containing $0.00 \mathrm{I} \mathrm{M}$-sodium ethylenediaminetetraacetate and $0.2 \%(\mathrm{v} / \mathrm{v})$ Triton X-Ioo (Sigma Chemical Co.) adjusted to $\mathrm{pH} 7 \cdot 0$ with $\mathrm{NaOH}$, in a motor-driven Daull all-glass tissue grinder (Kontes Glass Co., Vineland, NJ, USA). The homogenates and blood samples were then centrifuged at $\mathbf{2} 200 \mathrm{~g}$ for $5 \mathrm{~min}$ in a refrigerated MSE $2 \mathrm{~L}$ centrifuge (Measuring and Scientific Instruments Ltd, England) and the supernatant fractions of the homogenates and the blood plasma samples were retained for immediate determination of acid hydrolase activities.

Acid phosphatase $\left(E_{3} \cdot 1 \cdot 3 \cdot 2\right)$ was estimated by the method of Bessey, Lowry \& Brock (I946) with p-nitrophenylphosphate (Sigma Chemical Co.) as the substrate, in the presence or absence of Io $\mathrm{mM}-\mathrm{L}(+)$-sodium tartrate (Sigma Chemical Co.), $\mathrm{pH} 4.9$. The lysosomal activity was taken as the tartrate-inhibited portion of total activity, the remainder being attributed to the erythrocyte enzyme (Sawant, Desai $\&$ Tappel, I964). Supernatant fractions from the homogenates were incubated for $3 \circ \mathrm{min}$, and plasma samples for $60 \mathrm{~min}$, in a water bath at $37^{\circ}$ and, after deproteinization by addition of $0.25 \mathrm{ml}$ trichloroacetic acid $\left(25^{\circ} \mathrm{g} / \mathrm{l}\right.$ ) (final concentration $\left.5 \circ \mathrm{g} / \mathrm{l}\right)$, the $p$ nitrophenol released was estimated at $400 \mathrm{~nm}$ using a Unicam $\mathrm{SP}_{5} 00$ spectrophotometer (Unicam Instruments Ltd, Cambridge, England). One unit of activity represents I $\mu \mathrm{mol} p$-nitrophenol released $/ \mathrm{min}$.

Cathepsin $(E C 3 \cdot 4 \cdot 4.9)$ activity was determined at $\mathrm{pH} 5^{\circ} \circ$ with $N$-carbobenzoxyL-glutamyl-L-tyrosine (Sigma Chemical Co.) as substrate (Iodice \& Weinstock, 1965) in the presence of $4 \mathrm{~mm}$-mercaptoethanol (Sigma Chemical Co.). Supernatant fractions from the homogenates of liver and muscle were incubated with the substrate for 30 and 120 min respectively in a water bath at $37^{\circ}$ and, after deproteinization by released addition of $\mathrm{I} \mathrm{ml}$ trichloroacetic acid ( $100 \mathrm{~g} / \mathrm{l}$ ) (final concentration $5 \circ \mathrm{g} / \mathrm{l}$ ), the tyrosine was measured by reaction with ninhydrin (Spies, r957). This procedure measured cathepsin $\mathrm{A}$ together with any additional carboxypeptidase activity. One unit of activity represents I $\mu \mathrm{mol}$ tyrosine released $/ \mathrm{min}$.

\section{RESULTS}

\section{Protein-deficient rats}

Body-weights and tissue composition are shown in Figs $\mathrm{I}-3$. While rats ate the low-protein diet there was no increase in body-weight, but there was an immediate and rapid gain in weight as soon as they were rehabilitated. There was a dramatic fall in the protein:DNA ratio of livers from protein-deficient animals, although the ratio of liver weight to body-weight was maintained at a normal value. This is consistent with the infiltration by fat which was observed in livers from the protein-deficient group. In protein-deficient rats the total liver DNA content was maintained at a 


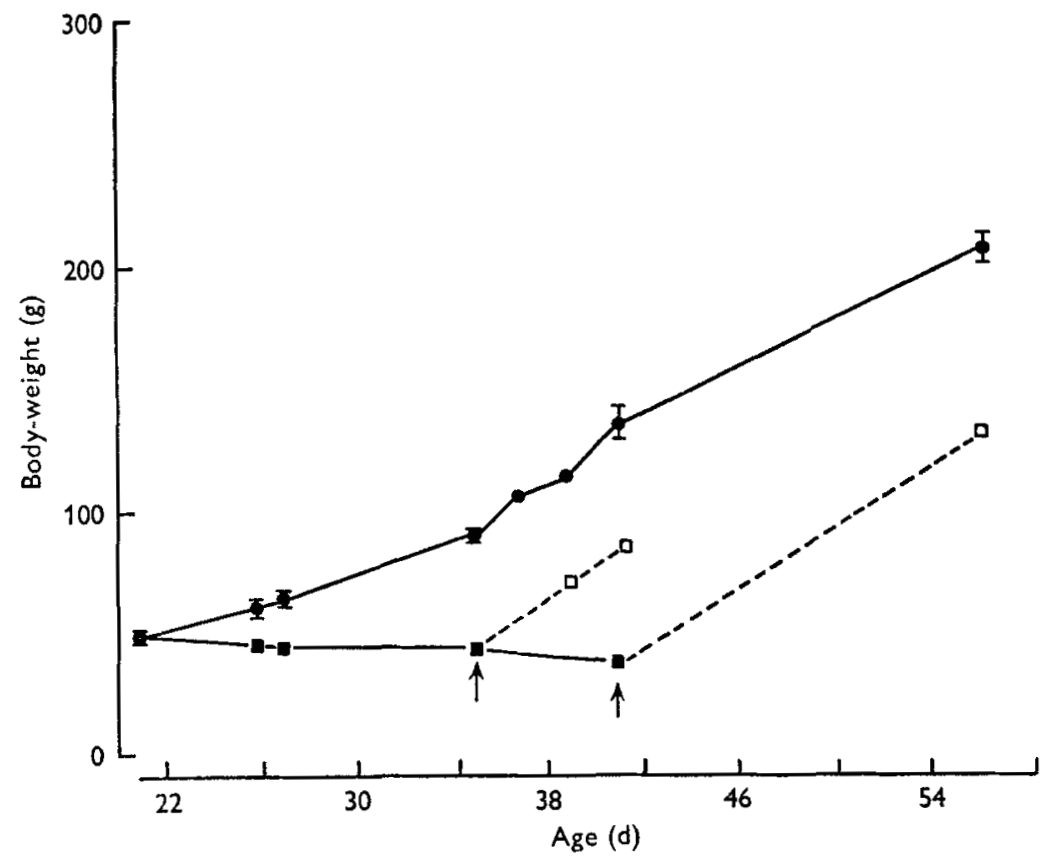

Fig. x. Body-weight of rats given Purina laboratory chow from weaning (e), or given a diet containing $10 \mathrm{~g}$ protein/kg either from weaning ( $\boldsymbol{\omega})$, or from weaning to the time indicated by the arrows and then Purina laboratory chow for 6 or $15 \mathrm{~d}(\square)$. Mean values with their standard errors, indicated as vertical bars. The results for both control and deficient rats on days 21,26 and 27 are for groups of eight rats. All other points represent groups of four rats.
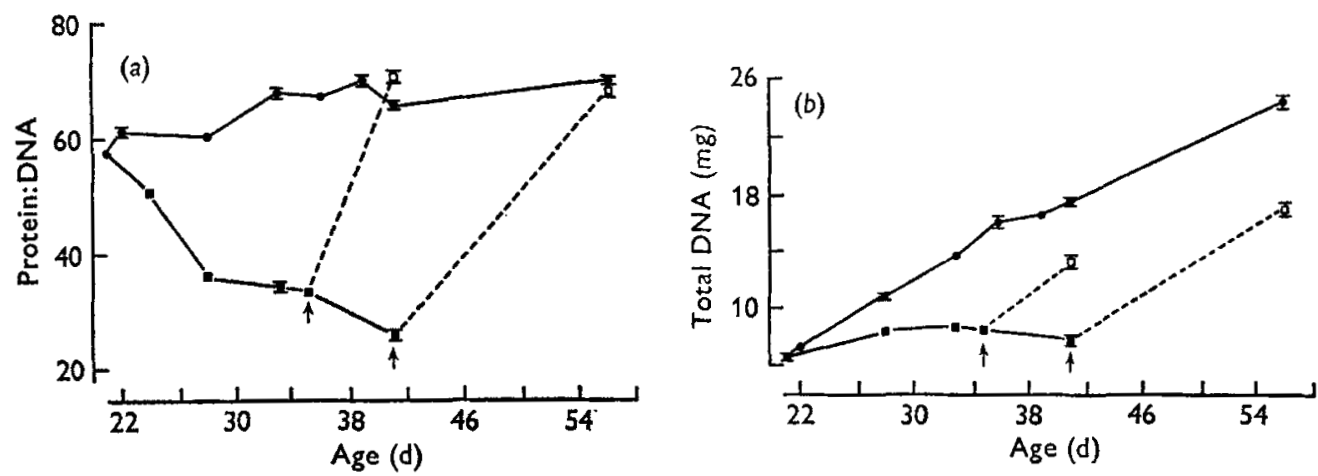

Fig. 2. The protein:DNA ratios $(a)$ and total DNA contents $(b)$ of livers from rats given Purina laboratory chow from weaning (O), or given a diet containing $10 \mathrm{~g}$ protein $/ \mathrm{kg}$ either from weaning ( $\boldsymbol{D})$, or from weaning to the time indicated by the arrows and then Purina laboratory chow for 6 or $15 \mathrm{~d}(\square)$. Mean values with their standard errors, indicated as vertical bars. The first point (day 21) represents results from five animals; all other points represent results from four animals. 


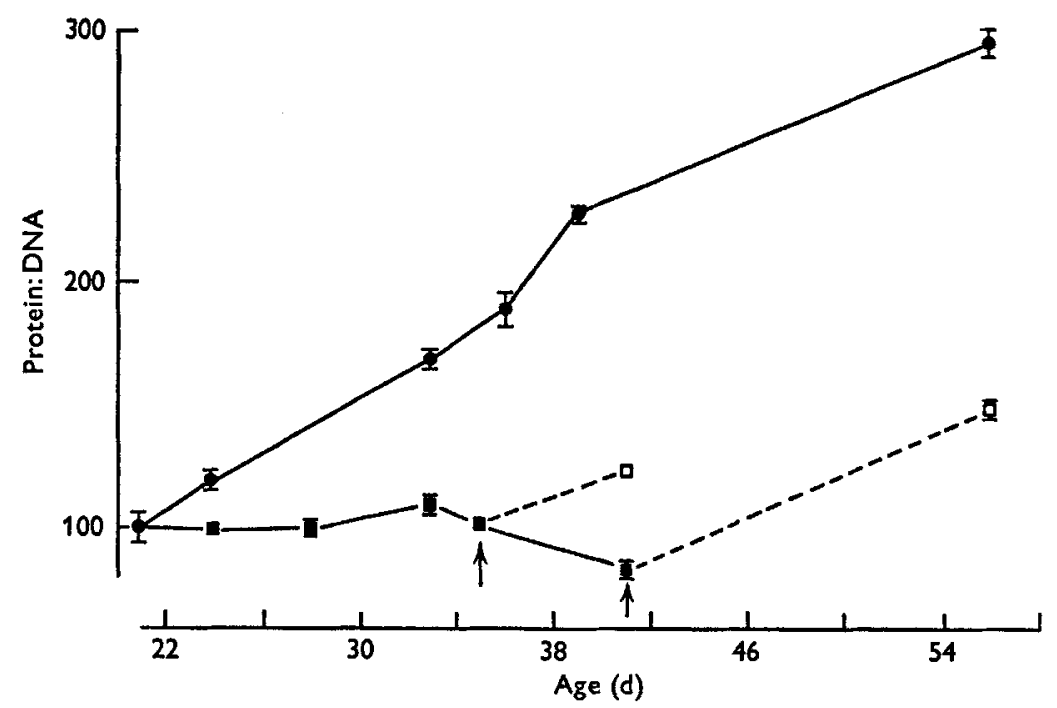

Fig. 3. The protein:DNA ratios of gastrocnemius muscle from rats given Purina laboratory chow from weaning (O), or given a diet containing ro $\mathrm{g}$ protein/ $\mathrm{kg}$ either from weaning ( $\square$ ), or from weaning to the time indicated by the arrows, and then Purina laboratory chow for 6 or $15 \mathrm{~d}(\square)$. Mean values with their standard errors, indicated as vertical bars. The first point (day $2 \mathrm{I}$ ) represents results from five animals, all other points represent results from four animals.

constant value. There was no change in muscle protein:DNA ratio for the first 2 weeks, although after 3 weeks on a low-protein intake, this value had fallen slightly, but not significantly, below the weaning value. During rehabilitation the total DNA content of the liver increased rapidly and a normal protein:DNA ratio was quickly achieved. Recovery in muscle protein:DNA ratio was slower and, over the period studied this ratio was still well below the control value.

When compared with control values, the acid hydrolase activity was significantly higher in the plasma and liver of rats given the low-protein diet for 5 and $14 \mathrm{~d}$, but was unchanged in muscle. However, after $20 \mathrm{~d}$ on this regimen, there was also a significant rise in acid phosphatase activity in the gastrocnemius muscle which coincided with a decrease in the muscle protein:DNA ratio (Table $\mathrm{I}$ ). After $6 \mathrm{~d}$ rehabilitation, amounts of plasma and liver acid phosphatase activities were significantly lower than control values, but after i $5 \mathrm{~d}$ (Table 2) the differences had lessened and were not statistically significant.

\section{$P E D$ rats}

Table 3 shows the body-weights and tissue composition for PED and control animals at weaning. Marked increases in lysosomal hydrolase activities were observed in the tissues of PED rats at this time (Table 4). Generally, the changes in enzyme activities were more striking than those observed in protein-deficient animals. After the rats had been weaned onto Purina laboratory chow for $7 \mathrm{~d}$, the enzyme activities were not statistically different from control values (Table 4 ). 
Table I. Lysosomal acid phosphatase (EC 3.1.3.2) and cathepsin (EC 3.4.4.9) activities estimated in supernatant fractions of liver and muscle homogenates (units* $/ g$ wet wt) and plasma samples (units*/ml) from rats maintained on Purina laboratory chow (control) or on diet containing $10 \mathrm{~g}$ protein $/ \mathrm{kg}$ (protein-deficient) from weaning

(Mean values with their standard errors; no. of animals in parentheses)

\begin{tabular}{|c|c|c|c|c|c|c|c|}
\hline \multirow[b]{3}{*}{$\begin{array}{l}\text { Age } \\
\text { (d) }\end{array}$} & \multirow[b]{3}{*}{ 'I'issue } & \multirow[b]{3}{*}{ Enzyme } & \multicolumn{4}{|c|}{ Enzyme activity } & \multirow{3}{*}{$\begin{array}{c}\text { Significance } \\
\text { of } \\
\text { difference } \\
\text { between } \\
\text { means }\end{array}$} \\
\hline & & & \multicolumn{2}{|c|}{ Control } & \multicolumn{2}{|c|}{ Protein-deficient } & \\
\hline & & & Mean & ${ }_{\text {SE: }}$ & Mean & $\hat{\wedge}----$ & \\
\hline $2 I$ & $\begin{array}{l}\text { Plasma } \\
\text { Liver }\end{array}$ & $\begin{array}{l}\text { Acid phosphatase } \\
\text { Acid phosphatase } \\
\text { Cathepsin }\end{array}$ & $\begin{array}{l}0.015 \\
2.650 \\
2.67\end{array}$ & $\begin{array}{l}0.001(5) \\
0.218(7) \\
0.41(4)\end{array}$ & & & \\
\hline & Muscle & $\begin{array}{l}\text { Acid phosphatase } \\
\text { Cathepsin }\end{array}$ & $\begin{array}{l}0.271 \\
0.29\end{array}$ & $\begin{array}{l}0.018(7) \\
0.08(4)\end{array}$ & & & \\
\hline 26 & $\begin{array}{l}\text { Plasma } \\
\text { Liver } \\
\text { Muscle }\end{array}$ & $\begin{array}{l}\text { Acid phosphatase } \\
\text { Acid phosphatase } \\
\text { Cathepsin } \\
\text { Acid phosphatase } \\
\text { Cathepsin }\end{array}$ & $\begin{array}{l}0.014 \\
2.801 \\
3.19 \\
0.275 \\
0.22\end{array}$ & $\begin{array}{l}0.003(4) \\
0.237(4) \\
0.77(4) \\
0.018(4) \\
0.04(4)\end{array}$ & $\begin{array}{l}0.028 \\
3.996 \\
3.51 \\
0.331 \\
0.21\end{array}$ & $\begin{array}{l}0.003(4) \\
0.227(4) \\
0.48(4) \\
0.024(4) \\
0.03(4)\end{array}$ & $\begin{array}{c}P<0.02 \\
P<0.01 \\
\text { NS } \\
\text { NS } \\
\text { NS }\end{array}$ \\
\hline 35 & $\begin{array}{l}\text { Plasma } \\
\text { Liver } \\
\text { Muscle }\end{array}$ & $\begin{array}{l}\text { Acid phosphatase } \\
\text { Acid phosphatase } \\
\text { Cathepsin } \\
\text { Acid phosphatase } \\
\text { Cathepsin }\end{array}$ & $\begin{array}{l}0.014 \\
2.750 \\
2.77 \\
0.279 \\
0.28\end{array}$ & $\begin{array}{l}0.001(4) \\
0.237(4) \\
0.36(4) \\
0.022(4) \\
0.03(4)\end{array}$ & $\begin{array}{l}0.027 \\
4.759 \\
3.59 \\
0.320 \\
0.30\end{array}$ & $\begin{array}{l}0.003(4) \\
0.173(4) \\
0.41(4) \\
0.027(4) \\
0.02(4)\end{array}$ & $\begin{array}{c}P<0.02 \\
P<0.001 \\
P<0.02 \\
\text { NS } \\
\text { NS }\end{array}$ \\
\hline $4 \mathrm{I}$ & $\begin{array}{l}\text { Plasrna } \\
\text { Iiver } \\
\text { Muscle }\end{array}$ & $\begin{array}{l}\text { Acid phosphatase } \\
\text { Acid phosphatase } \\
\text { Acid phosphatase }\end{array}$ & $\begin{array}{l}0.015 \\
2.794 \\
0.261\end{array}$ & $\begin{array}{l}0.001(4) \\
0.147(4) \\
0.001(4)\end{array}$ & $\begin{array}{l}0.027 \\
5 \cdot 198 \\
0.361\end{array}$ & $\begin{array}{l}0.002(4) \\
0.360(4) \\
0.033(4)\end{array}$ & $\begin{array}{l}P<0.005 \\
P<0.001 \\
P<0.025\end{array}$ \\
\hline
\end{tabular}

NS, not significant.

* One unit of acid phosphatase activity represents I $\mu \mathrm{mol} p$-nitrophenol rcleased/min. One unit of cathepsin activity represents I $\mu \mathrm{mol}$ tyrosine released $/ \mathrm{min}$.

\section{DISCUSSION}

There are two aspects of our results which should be considered. Whenever the protein:DNA ratios in the liver and muscle were lower than those of weanling rats, as in the livers of protein-deficient rats and in the livers and muscles of PED rats, then there were also increases in lysosomal hydrolase activities. In addition, there were marked differences between these two 'models of malnutrition', both in tissue composition changes and in the extent and distribution of changes in lysosomal hydrolase activities.

The protein:DNA ratios of tissues from malnourished animals differed from control values for at least two reasons. 'There may have been either retardation of growth which is perhaps indicated best by the total DNA content, or, alternatively, net loss of protein $\mathrm{N}$ from the tissues. In attempting to correlate lysosomal hydrolase activities with tissuc catabolism, it was necessary to decide the extent to which net loss of protein contributed to the altered protein:DNA ratios found in these malnourished animals. In protein-deficient rats the large decrease in protein:DNA ratio in the liver must have been associated with net loss of protein because the ratio was below the 
Table 2. Lysosomal acid phosphatase (EC 3.1.3.2) and cathepsin (EC 3.4.4.9) activities estimated in supernatant fractions of muscle and liver homogenates (units*/g wet wt) and plasma samples (units*/ml) from $4 \mathrm{I}$ - and 56 -d-old control rats (given laboratory chow from weaning) or rehabilitated rats (given a diet containing $10 \mathrm{~g}$ protein/kg for $\mathrm{I} 4 d$ followed by Purina laboratory chow for $6 d$ (dietary regimen $\mathrm{I}$ ) or for 20 d followed by Purina laboratory chow for ${ }_{1} 5 d$ (dietary regimen 2))

(Mean values with their standard errors; no. of animals in parentheses)

\begin{tabular}{|c|c|c|c|c|c|c|c|c|}
\hline \multirow{3}{*}{$\begin{array}{l}\text { Age } \\
\text { (d) }\end{array}$} & \multirow{3}{*}{$\begin{array}{l}\text { Diet- } \\
\text { ary } \\
\text { regi- } \\
\text { men }\end{array}$} & \multirow[b]{3}{*}{ Tissue } & \multirow[b]{3}{*}{ Enzyme } & \multicolumn{4}{|c|}{ Enzyme activity } & \multirow{3}{*}{$\begin{array}{c}\text { Significance } \\
\text { of } \\
\text { difference } \\
\text { between } \\
\text { means }\end{array}$} \\
\hline & & & & \multicolumn{2}{|c|}{ Control } & \multicolumn{2}{|c|}{ Rehabilitated } & \\
\hline & & & & Mean & $\mathrm{SE}$ & Mean & $\mathrm{SE}$ & \\
\hline $4 \mathrm{I}$ & I & $\begin{array}{l}\text { Plasma } \\
\text { Liver } \\
\text { Muscle }\end{array}$ & $\begin{array}{l}\text { Acid phosphatase } \\
\text { Acid phosphatase } \\
\text { Cathepsin } \\
\text { Acid phosphatase } \\
\text { Cathepsin }\end{array}$ & $\begin{array}{l}0.016 \\
2 \cdot 966 \\
2 \cdot 94 \\
0 \cdot 270 \\
0.39\end{array}$ & $\begin{array}{l}0.001(4) \\
0.162(4) \\
0.32(4) \\
0.022(4) \\
0.12(4)\end{array}$ & $\begin{array}{l}0 \cdot 009 \\
2 \cdot 232 \\
2 \cdot 46 \\
0 \cdot 236 \\
0 \cdot 32\end{array}$ & $\begin{array}{l}0.001(4) \\
0.115(4) \\
0.37(4) \\
0.011(4) \\
0.15(4)\end{array}$ & $\begin{array}{c}P<0.01 \\
P<0.02 \\
\text { NS } \\
\text { NS } \\
\text { NS }\end{array}$ \\
\hline $5^{6}$ & 2 & $\begin{array}{l}\text { Plasma } \\
\text { Liver } \\
\text { Muscle }\end{array}$ & $\begin{array}{l}\text { Acid phosphatase } \\
\text { Acid phosphatase } \\
\text { Acid phosphatase }\end{array}$ & $\begin{array}{l}0.015 \\
2.664 \\
0.274\end{array}$ & $\begin{array}{l}0.002(4) \\
0.115(4) \\
0.014(4)\end{array}$ & $\begin{array}{l}0.010 \\
2.412 \\
0.233\end{array}$ & $\begin{array}{l}0.002(4) \\
0.115(4) \\
0.032(4)\end{array}$ & $\begin{array}{l}\text { NS } \\
\text { NS } \\
\text { NS }\end{array}$ \\
\hline
\end{tabular}

NS, not significant.

* One unit of acid phosphatase activity represents $1 \mu \mathrm{mol} p$-nitrophenol released/min. One unit of cathepsin activity represents I $\mu \mathrm{mol}$ tyrosine released $/ \mathrm{min}$.

Table 3. Protein and DNA contents of liver and muscle samples from $2 \mathrm{I}-d$-old rats suckled sixteen/dam (protein-energy deficient (PED)) or eight/dam (control)

(Mean values with their standard errors; no. of animals in parentheses)

\begin{tabular}{|c|c|c|c|c|c|c|}
\hline & \multirow[b]{2}{*}{ Tissue } & \multicolumn{2}{|c|}{ Control } & \multicolumn{2}{|c|}{ PED } & \multirow{2}{*}{$\begin{array}{c}\text { Significance } \\
\text { of } \\
\text { difference } \\
\text { between } \\
\text { means }\end{array}$} \\
\hline & & Mean & $\mathrm{SE}$ & Mean & $\mathrm{SE}$ & \\
\hline \multirow{3}{*}{$\begin{array}{l}\text { Body-wt (g) } \\
\text { Protein:DNA } \\
\text { (ratio by wt) }\end{array}$} & & $55^{2} \cdot 2$ & $2 \cdot 8(5)$ & $30 \cdot 1$ & $I \cdot 9(6)$ & $P<0.001$ \\
\hline & Liver & $52 \cdot 2$ & $0.7(5)$ & $42 \cdot 2$ & $2 \cdot 8(6)$ & $P<0.02$ \\
\hline & Muscle & $95^{\circ} 0$ & $5 \cdot I(5)$ & $55 \cdot 7$ & $1 \cdot 8(6)$ & $P<0.001$ \\
\hline Total DNA (mg) & Liver & $7 \cdot 56$ & $0.30(5)$ & $4 \cdot 89$ & $0.24(6)$ & $P<0.001$ \\
\hline
\end{tabular}

value found in the normal weanling rat, while total DNA content had changed little. In PED rats the subnormal values for total liver DNA indicated that there had been some retardation of growth of this organ and hence the lowered liver protein:DNA ratio of these animals may have resulted from both retardation of growth and increased protein catabolism. In the absence of results for total muscle DNA we are unable to say whether the decrease in muscle protein:DNA ratio found in PED rats was due to net protein loss.

The results in Tables $\mathrm{I}-4$ showed that increased amounts of lysosomal hydrolases occur only in those tissues which had subnormal protein:DNA ratios. It therefore seems possible that these enzymes are involved in the protein catabolism which occurs in malnutrition. However, since liver cathepsin was not significantly increased when protein loss from this organ was maximal, i.e. during the first $6 \mathrm{~d}$ on a low-protein 
Table 4. Lysosomal acid phosphatase (EC 3.I.3.2) and cathepsin (EC 3.4.4.9) activities estimated in supernatant fractions of liver and muscle homogenates (units*/g wet wt) and plasma samples (units*/ml) from $2 \mathrm{I}$-d-old rats suckled sixteen/dam (proteinenergy deficient $(P E D)$ ) or eight/dam (control), then weaned onto Purina laboratory chow for $7 d$

(Mean values with their standard errors; no. of animals in parentheses)

\begin{tabular}{|c|c|c|c|c|c|c|c|}
\hline \multirow{3}{*}{$\begin{array}{l}\text { Age } \\
\text { (d) }\end{array}$} & \multirow[b]{3}{*}{ Tissue } & \multirow[b]{3}{*}{ Enzyme } & \multicolumn{4}{|c|}{ Enzyme activity } & \multirow{3}{*}{$\begin{array}{c}\text { Significance } \\
\text { of } \\
\text { difference } \\
\text { between } \\
\text { means }\end{array}$} \\
\hline & & & \multicolumn{2}{|c|}{ Control } & \multicolumn{2}{|c|}{ PED } & \\
\hline & & & Mean & $\mathrm{SE}$ & Mean & SE & \\
\hline \multirow[t]{4}{*}{$2 \mathrm{I}$} & Plasma & Acid phosphatase & 0.015 & $0.001(5)$ & 0.056 & $0.008(7)$ & $P<0.005$ \\
\hline & & Acid phosphatase & 2.650 & $0.218(7)$ & 4.370 & $0.379(8)$ & .005 \\
\hline & & Cathepsin & $2 \cdot 67$ & $0.41(4)$ & $3 \cdot 5$ & 0.35 & $P<0.02$ \\
\hline & Muscle & $\begin{array}{l}\text { Acid phosphatase } \\
\text { Cathepsin }\end{array}$ & $\begin{array}{l}0.271 \\
0.29\end{array}$ & $\begin{array}{l}0.018(7) \\
0.08(4)\end{array}$ & $\begin{array}{l}0.454 \\
1.08\end{array}$ & $\begin{array}{l}0.048(8) \\
0.28(4)\end{array}$ & $\begin{array}{l}P<0.01 \\
P<0.005\end{array}$ \\
\hline \multirow[t]{5}{*}{28} & Plasma & Acid phosphatase & 0.012 & 0.002 (4) & 0. & $0.001(4)$ & NS \\
\hline & Liver & Acid phosphatase & $2 \cdot 678$ & 0.140 & $2 \cdot 218$ & 0.169 & NS \\
\hline & & Cathepsin & $2 \cdot 75$ & $0.39(4)$ & $2 \cdot 25$ & 0.48 & NS \\
\hline & Muscle & Acid phosphatase & 0.295 & $0.027(4)$ & 0.309 & $0.048(4)$ & NS \\
\hline & & Cathepsin & $0.3 \mathrm{I}$ & $0.13(4)$ & 0.39 & $0 \cdot 18(4)$ & NS \\
\hline
\end{tabular}

NS, not significant.

* One unit of acid phosphatase activity represents I $\mu \mathrm{mol} p$-nitrophenol released/min. One unit of cathepsin activity I $\mu \mathrm{mol}$ tyrosine released/min.

diet, these enzymes may not be the predominant influence in the early stages of protein depletion.

During rehabilitation, there was a tendency for lysosomal hydrolase activity to be reduced below normal values. A similar observation was made by Millward (1972) and indicates that the rapid growth during rehabilitation may be achieved in part by a reduction in protein catabolism. It is of interest that in skeletal muscle, in which recovery of normal composition was slow, the hydrolase concentrations fell, but not as markedly as in liver, which recovered a normal protein:DNA ratio rapidly on rehabilitation.

It has already been pointed out that there were differences between the two 'models of malnutrition' used in this study. In protein-deficient rats there was no significant decrease in muscle protein: DNA ratio, while in PED rats this ratio was considerably lower than the control value. This finding was consistent with the different dietary regimens of the two groups. During the first $15 \mathrm{~d}$ on an ad lib. low-protein diet, the rats maintained an adequate energy intake and skeletal muscle protein may have been conserved. We have observed that food intake was reduced when animals were maintained on this diet for longer than $\mathrm{r}_{5} \mathrm{~d}$, and it is possible that the small decrease in muscle protein : DNA ratio after 3 weeks on a low-protein diet was caused by an increase in muscle-protein catabolism in response to inadequate energy intake. PED rats have an inadequate intake of protein and energy and in these animals increased muscle catabolism may be required to provide an energy source. 
PED rats show an increase of acid hydrolase activity in the liver, and this is seen also in the protein-deficient rats after they have been given the low-protein diet for $\mathrm{I}_{4} \mathrm{~d}$. The tissue damage which accompanied fat infiltration of the liver in proteindeficient animals may contribute to the rise in acid hydrolase activity in the liver in this group. Plasma acid phosphatase increased most markedly in the PED group which is consistent with the more generalized increase of hydrolase activities in the tissues of these animals.

The stimulus for increased lysosomal enzyme activity in malnourished rats is not known, although some of the changes in endocrine activity associated with malnutrition (for review see Waterlow \& Alleyne, 197 I) may be involved. It should be emphasized here that the present study measured only total acid hydrolase activity. The latency of these enzymes was not investigated. Lysosome stability is modified in vivo and in vitro by a variety of hormones, particularly steroid hormones (Weissmann, 1964). It is therefore quite possible that changes in latency are superimposed on the increases in total enzyme activity which we have observed in malnourished rats.

\section{REFERENCES}

Begum, A. \& Ittyerah, T. R. (1970). Clinica chim. Acta 28, 263.

Bessey, O. A., Lowry, O. H. \& Brock, M. J. (1946). F. biol. Chem. 164, 321.

Bird, J. W. C., Berg, T. \& Leatham, J. H. (1968). Proc. Soc. exp. Biol. Med. 127, 182.

Flores, H., Sierralta, W. \& Monckeberg, F. (r970). F. Nutr. 100, 375.

Iodice, A. A. \& Weinstock, I. M. (1965). Nature, Lond. 207, I 102.

Ittyerah, T. R., Dumm, M. E. \& Bachhawat, B. K. (r967). Clinica chim. Acta 17, 405.

Kennedy, G. C. (1957). J. Endocr. 16, 9.

Koszalka, T. R., Mason, K. E. \& Krol, G. (196r). F. Nutr. 73, 78.

Lowry, O. H., Rosebrough, N. J., Farr, A. L. \& Randall, R. J. (1951). F. biol. Chem. 193, 265.

Max, S. R., Mayer, R. F. \& Vogelsang, L. (1971). Archs Biochem. Biophys. 146, 227.

Mendes, C. B. \& Waterlow, J. C. (1958). Br. F. Nutr. 12, 74.

Millward, D. J. (1970). Clin. Sci. 39, 591 .

Millward, D. J. (1972). Proc. Nutr. Soc. 31, 3A.

Munro, H. N. (1964). In Mammalian Protein Metabolism Vol. I, Ch. Io [H. N. Munro and J. B. Allison, editors]. London and New York: Academic Press.

Munro, H. N. \& Fleck, A. (1969). In Mammalian Protein Metabolism Vol. 3, p. 482 [H. N. Munro and J. B. Allison, editors]. London and New York: Academic Press.

Novikoff, A. B., Essner, E. \& Quintana, N. (1964). Fedn Proc. Fedn Am. Socs exp. Biol. 23, тоro.

Sawant, P. L., Desai, I. D. \& Tappel, A. L. (1964). Biochim. biophys. Acta 85, 93.

Spies, J. R. (1957). In Methods in Enzymology Vol. 3, p. 468 [S. P. Colowick and N. O. Kaplan, editors]. New York: Academic Press.

Tappel, A. L., Zalkin, H., Caldwell, K. A., Desai, I. D. \& Shibko, S. (1962). Archs Biochem. Biophys. 96, 34 .

Waterlow, J. C. \& Stephen, J. M. L. (1968). Clin. Sci. 35, 287.

Waterlow, J. C. \& Alleyne, G. A. O. (1971). Adv. Protein Chem. 25, I17.

Weissmann, G. (1964). Fedn Proc. Fedn Am. Socs exp. Biol. 23, 1038.

Widdowson, E. M. \& McCance, R. A. (1960). Proc. R. Soc. B 152, i 88.

Zalkin, H., Tappel, A. L., Caldwell, K. A., Shibko, S., Desai, I. D. \& Holliday, T. A. (1962). F. biol. Chem. $\mathbf{2 3 7}, \mathbf{2 6 7 8 .}$ 